811.163.41'367

https://doi.org/10.18485/sj.2019.24.1.19

МИЈАНА Ч. КУБУРИТ МАЦУРА*

Универзитет у Бањој Луци

Филолошки факултет
Оригинални научни рад Примљен: 09. 10. 2018. Прихваћен: 15. 01. 2019.

\title{
АДВЕРЗАТИВНЕ РЕЧЕНИЦЕ С КОНЦЕСИВНИМ СМИСАОНИМ ОДНОСОМ У СРПСКОМ ЈЕЗИКУ
}

У раду се представља анализа и систематизација адверзативних реченица којима се исказује концесивни смисаони однос у савременом српском језику. Највећи број оваквих адверзативних клауза има узрочноконцесивну логичку импликацију, али под одређеним синтаксичким и семантичким околностима реализује се и условноконцесивна семантика. Овакве клаузе (са условноконцесивном вриједношћу) јављају се често и као асиндетске клаузе, при чему показују велику структурну разноврсност која се тиче прве клаузе. Реченице које испуњавају само нужан услов логичке супротстављености и неиспуњеног очекивања и имају одговарајући везник не могу се сматрати правим представницима концесивног семантичког подтипа координираних реченица, мада, евидентно, имају концесивно значење као саприсутно у својој адверзативној семантици. Све док није испуњен трећи, синтаксички најрелевантнији услов за концесивну семантичку интерпретацију координираних садржаја - присуство конкретизатора или модификатора везничког значења, концесивна компонента представља тек једну од потенцијалних логичких импликација таквих садржаја.

Кључне ријечи: концесивност, адверзативност, конкретизатор везничког значења, модификатор везничког значења.

*mijana.kuburic-macura@flf.unibl.org 


\section{1. УВОД}

\section{1. Структура концесивног значења}

Концесивност спада у групу сложених релационих категорија које оформљују категоријални комплекс каузалности, тј. које карактерише двочлани каузални низ (Милошевић 1986: 34, Пипер и др. 2005: 813). Концесивна релација у најопштијем смислу представља семантички вишеслојну релацију чија се структура може одредити само анализом односа опречности, али и сродности и сличности са неколико других мисаоних и језичких категорија, на првом мјесту са категоријама кондиционалности, каузалности и адверзативности. Концесивна релација, у својој основи, као и каузална и кондиционална, почива на вези између два фактора који учествују у њеном остваривању, а то су основ и посљедица. При томе је узрочно-посљедична веза међу појавама, као и веза услова и условљеног, која је узрочној вези сродна у толикој мјери да се узрочна из ње изводи, ${ }^{1}$ и у природи - ванјезичкој стварности и у језику, најприроднији тип везе који је дубоко усађен у наше поимање свијета. Међутим, у концесивном контексту појављује се посљедица супротна оној коју очекујемо на темељима експлицираног основа. Концесивно значење је, на исти начин, сродно и са кондиционалним, јер језичке јединице које служе за исказивање концесивности, исто као и оне којима се изражава кондиционалност, представљају неки услов за извршење глаголске радње, али се прави услов и концесивни услов разликују на основу своје адекватности ефекту који производе. Дакле, укључивањем значења супротности у логички однос између узрока/услова и логично очекиване посљедице нарушава се „природан” слијед догађаја предодређен узрочно-посљедичним поретком у језику и мишљењу, и нарушавањем тог односа долази до резултата који је супротан од очекиваног и претпостављеног на основу начела ванјезичког искуства.

\section{2. Преглед литературе}

На допусни смисаони однос као подтип односа супротности у језику у нашој лингвистици први је указао М. Ајановић у раду у којем критикује традиционална схватања независносложених реченица као реченица у којима клаузе стоје у лабавом односу, односу скоро потпуне самосталности (Ајановић

\footnotetext{
${ }^{1}$ На чињеницу да се разлог, тип узрока, мора истраживати најприје као услов, и да узрочност, у ствари, представља само један тип условљености указали су још филозофи материјалистичке дијалектике (нпр. Блох 1980: 134-137), а Милош Ковачевић ту везу објашњава на сљедећи начин: „Као и у природи, и у језику је узрочно-посљедична веза у ствари подврста везе услова и условљеног. Тако се реченице што обиљежавају узрок и услов разликују само модусом везе. Узрок је увијек реални (фактивни) услов, док је услов потенцијални (замишљени) узрок. Тако се разлика између те двије категорије у језику огледа у односу могућност (услов) - стварност (узрок).” (Ковачевић 1988: 48)
} 
1953, 1954a, 1954б). Аутор тврди и доказује да аутори граматика занемарују чињеницу да везници независносложених реченица, поред функције везивања, имају и додатну семантичку компоненту која везу међу клаузама чини довољно јаком да се оне не могу просто раздвојити без промјене у значењу. Анализом примјера независносложених реченица које се могу наћи у свим традиционалним граматикама, Ајановић показује да односи у координацији нису потпуно независни и да сваки од типова независносложених реченица има своје семантичке подтипове. Тако он у оквиру супротних реченица издваја и подтип са допусним значењем, који поткрепљује примјерима из граматика: „Он је паметно говорио, али је у неким стварима претјерао; Ја псето вадим, а оно ме уједа; Игла кроз злато и сребро прође па је опет гола; Ја сам царица, пак немам златног разбоја" (Ајановић 1953: 139). Међутим, уз трећи дио Ајановићеве расправе, Александар Белић објављује критику Ајановићевог виђења односа међу сложеним реченицама, чија је суштина указивање на разлику између логичке, тј. смисаоне зависности, у коју независносложене реченице могу ступати на основу свог смисла, и функционалне - граматичке, тј. синтаксичке зависности, коју независносложене реченице, по својој суштини, искључују, јер немају ни функционалне ни формалне (везничке) услове за њу (Белић 1954: 227-234).

Занимљива запажања о супротности и супротним реченицама даје М. Стевановић. Он наводи да се супротним реченицама називају оне реченице у којима оно што се њима казује стоји у некој међусобној вези по смислу, али је оно што се износи у другој по нечему супротно или барем неподударно са садржајем претходне реченице. Као везнике супротних реченица Стевановић наводи сљедеће: $a$, али, већ, него, но, док, па ипак, па и при том, па и поред тога, пак, међутим итд., међу којима су, дакле, и везници са концесивним конкретизаторима везничког значења (Стевановић 1969: 767-783). Стевановић разликује двије врсте супротности које се исказују независним супротним клаузама, а то су права супротност и неподударност. Из примјера које наводи да би илустровао значење праве супротности видимо да је права супротност, у ствари, концесивност. У реченицама којима се исказује права супротност, како наводи Стевановић (1969: 769-771), јавља се случај да се једном клаузом износи нешто што је супротно од онога што би се очекивало према садржини друге, са њом напоредне клаузе, тј. једном реченицом се констатује „да се нешто врши или нешто јест, и поред тога што из садржине оне друге реченице то не бисмо очекивали" (Стевановић 1969: 769). Са друге стране, супротност - неподударност је најблажи тип супротности и њоме се казује само неподударност неких реченичних чланова.

Кад је у питању наша новија литература, односа супротног и концесивног значења, као и односа синтаксичких јединица којима се ова значења исказују, дотичу се Иво Прањковић, Ксенија Милошевић и Милош Ковачевић. 
Иво Прањковић, у студији о координацији у хрватском језику (1984: 37-38), критикује превише усложњену подјелу координираних реченица и предлаже подјелу на три основна типа: саставне, супротне и раставне. Пишући о оваквој подјели и дајући аргументе против издвајања закључних и искључних реченица као посебних типова, квалификујући их као смисаоне односе међу клаузама саставних и супротних реченица, Прањковић као посебан смисаони однос који се може исказивати супротним реченицама наводи и концесивни однос („Видиш, ја сам ослобођена од заклетве, а ипак сваки који окуси моју љубав, моју безумну страст, мора умријети и остати вјечно уза ме да ми свира чаробне мелодије (Раос, 28)"). К. Милошевић (1986: 41) наводи да адверзативни везници $a$ и али могу да се јаве као концесивни конектори, а М. Ковачевић, у раду у ком даје критику издвајања закључних и искључних клауза као посебних врста (Ковачевић 1998: 39), као један од семантичких подтипова супротности, поред односа конфронтације, компензације, ексклузивности и других, издваја и однос концесивности као један од смисаоних односа који се изражавају супротним реченицама, и илуструје га примјером: „Није био јачи, ни паметнији, ни старији од осталих дечака у дружини, а ипак су га сви слушали (Д. Ненадић, 108)".

Најновији наши граматички приручници у правилу помињу способност адверзативних реченица да исказују концесивни смисаони однос. Тако аутори Нормативне граматике српског језика наводе да дијелови супротне реченице с везницима $a$ и али могу бити у међусобној логичкој условљености, на првом мјесту допусној (Пипер и Клајн 2017: 482). У Граматищи се такође наводи и да, у зависности од лексичког састава реченице у којој је везник али употријебљен, његово значење може бити спецификовано као временско, просторно, компензативно, допусно, квалификативно или др., а кад се везник али употребљава у супротним реченицама с допусним значењем, умјесто њега се понекад користи „везнички израз” па ипак или, рјеђе, везник но (Пипер и Клајн 2017: 486). Исто ово наводи се и у Синтакси сложене реченице у савременом српском језику (Пипер и др. 2018: 73), а у поглављу о асиндетским реченицама С. Танасић пише и о примјерима у којима се јавља конкретизатор допусног значења, наводећи примјер „У тиму су га запазили сви, ипак му тренер није дозволио да започне утакмицу" и др. Овдје се наводи и да су овакве реченице у језику ријетке и да се предикацијска цјелина с конкретизатором често осамостаљује (Пипер и др. 2018: 621). 


\section{2. АДВЕРЗАТИВНЕ РЕЧЕНИЦЕ С КОНЦЕСИВНОМ ЛОГИЧКОМ ИМПЛИКАЦИЈОМ}

Да би се адверзативним реченицама уопште могли исказати концесивни смисаони односи, први и неопходан услов је тај да адверзативни садржаји у својој семантици имају концесивну логичку импликацију - у првој клаузи се износи неадекватан основ за реализацију садржаја који слиједи у другој клаузи. Употреба везника овдје, као ни у случају чисте адверзативности, без примјеса концесивног значења, није нужан услов, јер се у језику срећу и асиндетске супротне реченице са концесивном семантиком. Када су у питању синдетске адверзативне реченице, са експлицираним везником, за исказивање концесивних односа оспособљени су само везници али и $a$, као и нешто рјеђе но, али само у ситуацијама када је замјењиво са $a$ или али. Преостала два супротна везника, него и већ, немају способност да повезују садржаје који стоје у односу смисаоне концесивне повезаности - они увијек означавају чисту супротност, без примјеса других значења. ${ }^{2}$

Адверзативне реченице са концесивном семантиком могу се, на основу тога да ли је њихова концесивна интерпретација контекстуално условљена или није, разврстати у двије основне групе: адверзативне реченице са имплицитним (контекстуално условљеним) концесивним значењем и адверзативне реченице с конкретизаторима везничког значења (с контекстуално неусловљеним значењем).

\section{1. Адверзативне реченице са имплицитном (контекстуално условљеном) концесивном семантиком}

Адверзативне реченице са контекстуално условљеним значењем концесивности су оне код којих концесивни однос међу клаузама није прецизиран и потврђен никаквим специфично концесивним формалним средством (конкретизатором концесивног значења), већ је заснован искључиво на имплицитној концесивној релацији међу садржајима. Њихова концесивна интерпретација заснива се, дакле, само на чињеници да садржаји њима исказани стоје у односу који подразумијева да један од реченичних садржаја представља неадекватан основ за реализацију другог, тј. на основу првог садржаја не би се очекивала реализација другог, али до тога ипак долази.

Адверзативном клаузама са имплицитном концесивном семантиком може се исказивати и узрочноконцесивни и условноконцесивни тип значења.

\footnotetext{
${ }^{2}$ Супротност - неподударност, која нема неку додатну логичку импликацију (можемо то
} тврдити на основу ниске фреквентности таквих примјера у корпусу) у језику је ријетка. 


\subsection{1. Реченице са узрочноконцесивном семантиком}

У овом типу адверзативних реченица, концесивно значење заснива се на неадекватности узрока, тј. први реченични садржај увијек представља неадекватан реални основ за реализацију другог по реду адверзативног садржаја, уведеног везником. ${ }^{3}$ Неки од таквих примјера су сљедећи:

Мучи се човјек довијека $a$ никад нема ни оно што му треба а камоли оно што жели. (Андрић, 295); Помислио сам да ће рећи да ваздух није безбојан, личио ми је на такву особу, на некога ко увек, премда ненаметљиво, саопштава право стање ствари, али он је само сркао супу и повремено гледао кроз прозор. (Албахари, 7); Малишан је Ирени био окренут леђима, главу није померио, али је изгледало да је сасвим свестан да она стоји ту иза њега. (Куић, 98); Лијепо су му поручили да дође себи, али он је мислио да га се боје, и није престао да чини оно што никоме није било од користи. (Селимовић, 93); и др.

У свим наведеним примјерима, адверзативни везници повезују садржаје који имају концесивну логичку импликацију - у првој клаузи се износи неадекватан основ за реализацију садржаја који слиједи и који се уводи клаузом која започиње адверзативним везником. Услов који овакве адверзативне клаузе морају испунити да би њихова веза, као саприсутну, имала концесивну вриједност јесте да прва клауза представља неадекватан основ за реализацију друге по реду клаузе, али да се ситуација исказана другом клаузом реализује упркос тој неадекватности. У свим наведеним адверзативним клаузама, другом у низу клаузом казује се да се реализује нешто супротно од онога што би се очекивало на основу ситуације представљене у првој клаузи. Таква логичка неадекватност је у свим примјерима заснована на контексту и није маркирана никаквим специфично концесивним средством. У свим оваквим реченицама, супротстављене ситуације се јављају као реалне, спознате, евидентне ситуације у чију реализацију и истинитост нема сумње, тако да можемо рећи да се у свим досад наведеним адверзативним реченицама са концесивном семантиком јавља узрочноконцесивни тип концесивног значења.

${ }^{3}$ Узрочноконцесивна семантика може се исказивати и асиндетским реченицама у којима је евидентна имплицитна адверзативност. О томе детаљно пише Иво Прањковић: „За изрицање односа допусности међу дијеловима структура (међу реченицама) готово да су резервиране експлицитне субординиране реченице. Посебно је ријетка нетипизирана имплицитна допусност. То, међутим, није посебно тешко објаснити: за допусне реченице (у експлицитној субординацији) карактеристична је корелативност мање или више устаљених средстава којима се изриче тај однос (нпр. иако - ипак или сл.), а у нетипизираним допусним структурама таква средства изостају или бивају и у једном и у другом дијелу структуре интонативно компензирана. Стога се структуре тога типа одликују стилском обиљеженошћу и најчешће су у разговорном стилу (фуснота: Један од разлога за то свакако се крије у чињеници да ситуативност разговорног стила увјетује специфичан начин интонативне реализације), на примјер: Чекали смо до јутра - нитко се није појавио; Покушали смо све што нам је пало на памет - било је узалуд; Нитко их није звао, сами су дошли" (Прањковић 2002: 174). Наведено вјероватно представља разлог зашто у корпусу који представља основу за ово истраживање, из којег је искључен разговорни језик, нисмо забиљежили овакве асиндетске структуре. 
Све наведене клаузе на семантичком плану еквивалентне су адверзативним клаузама у које бисмо увели концесивни конкретизатор везничког значења, нпр. партикулу ипак:

Мучи се човјек довијека $a$ никад нема ни оно што му треба а камоли оно што жели. [ $\rightarrow$ Мучи се човјек довијека $a$ ипак никад нема ни оно што му треба а камоли оно што жели]; Био је човек дивовског раста али је пропао у многим ратовима у којима се прославио. [ $\rightarrow$ Био је човек дивовског раста али је ипак пропао у многим ратовима у којима се прославио]; и др.

\subsection{2. Реченице са условноконцесивном семантиком}

Знатно нижом фреквенцијом (али већом формалном разноврсношћу) одликују се супротне клаузе са имплицитном условноконцесивном семантиком, тј. реченице у којима први садржај нема сазнајно потврђену вриједност и који се јавља као неадекватан/ недовољан услов за реализацију другог по реду садржаја. На основу тога да ли се јављају у синдетској или асиндетској форми, овакве реченице подијелићемо у двије основне врсте.

\subsubsection{1. СИНДЕТСКЕ РЕЧЕНИЦЕ СА УСЛОВНОКОНЦЕСИВНОМ СЕМАНТИКОМ}

Адверзативне реченице са контекстуално условљеном условноконцесивном семантиком у којима се јављају експлицирани везници показују одређене специфичности које се тичу глаголских облика у позицији предиката.

Први тип таквих реченица су нпр. сљедеће:

Ламенто може бити заводљиво људски, али не погађа ствар. (Живановић, 30); Можеш негде да отпутујеш, рекао је, можеш да се настаниш на другом континенту, можеш да обрађујеш неку другу њиву, али никада из себе, испод својих ноктију, из свог срца, нећеш уклонити ону првотну земљу, ону плодну црницу (...) (Албахари, 145) и др.

У наведеним примјерима се у првима од супротних клауза јавља модални глагол у предикату, који „релативизује” фактивност глаголске радње која представља основ за извршење друге по реду радње. На тај начин се реални, фактивни неадекватни основ преводи у евентуални, потенцијални неадекватни основ, тј. неадекватни узрок се преводи у неадекватни услов. Да се имплицитно у оваквим супротним клаузама јавља условноконцесивни тип концесивног значења, можемо показати трансформацијом ових реченица у реченице са условноконцесивном зависном клаузом:

Ламенто може бити заводљиво људски, али не погађа ствар. [ $\rightarrow$ Ако је и заводљиво људски, ламенто не погађа ствар.]; Можеш негде да отпутујеш, рекао је, можеш да се настаниш на другом континенту, можеш да обрађујеш неку другу њиву, али никада из себе, испод својих ноктију, из свог срца, нећеш уклонити ону првотну земљу, ону плодну црницу $(\ldots)$. $\rightarrow$ Ако и отпутујеш негдје (...), ако се и настаниш на другом континенту, никада из себе (...) нећеш уклонити ону првотну земљу, ону плодну црницу (...)]. 
Такође, условноконцесивну семантику имају и неке супротне реченице у којима се у првој од клауза јавља предикат у облику футура, нпр.:

Страдаћу, али га не дам. (Селимовић, 361).

Овако употријебљеним обликом футура исказује се спремност на „подношење жртве", на прихватање свих негативних посљедица у жељи да се реализује радња из друге по реду клаузе:

Страдаћу, али га не дам [ $\rightarrow$ Макар страдао, ја га не дам].

Као посебан формалносинтаксички тип супротних реченица са условноконцесивном интерпретацијом појављују се и оне у којима се у првој од клауза јавља облик императива, било „прави” императив за друго лице, било облик императива за треће лице који се гради помоћу партикуле нека:

Сасијеци ти Ђулагу до коријена, $a$ други ће ти Ђулага сам доћи (...) (Ћопић, 80-81) $[\rightarrow$ Макар ти сасјекао Ђуласу до коријена, други ће ти Ђулага сам доћи (...)]; Уосталом, свеједно, нека је и површан, нека је и лакомислен, нека проћердава своју несвакидашњу памет како хоће, али је добар човјек и зна тајну да буде пријатељ. (Селимовић, 112) [ $\rightarrow$ (...) макар био и повриан, макар био и лакомислен, макар проћердавао своју несвакидашњу памет како хоће, он је добар човјек и зна тајну да буде пријатељ]; Нека ми их отфикаре [ноге] ... пси нека их развлаче и глођу, али нећу да се макнем... (Булатовић, 89) [ $\rightarrow$ Макар ми отфикарили ноге, макар их пси развлачили и глодали, ја нећу да се макнем]; и др.

\subsubsection{2. АСИНДЕТСКЕ РЕЧЕНИЦЕ СА УСЛОВНОКОНЦЕСИВНОМ СЕМАНТИКОМ}

Условноконцесивно значење може се исказивати и неким асиндетским адверзативним реченицама. На првом мјесту, то су реченице код којих, како то наводи Ксенија Милошевић (1986: 38), глаголска лексема у позицији предиката сугерише концесивни однос. На примјер:

Можете провести поред њега још двадесет година, ништа подробније више о њему немате да сазнате. (Милошевић, 1986: 38); Погинућу, њу не дам! (еНовости, 196) и др.

У првом примјеру, такође, глаголска лексема „моћи”, која у себи садржи значење могућности, у ствари, како пише Ксенија Милошевић, „компензира значење модалног глаголског облика, и то потенцијала, у којем се исто значење манифестује и као граматичко” (Милошевић 1986: 38):

Можете провести поред њега још двадесет година $[\rightarrow$ Макар провели поред њега још двадесет година], ништа подробније више о њему немате да сазнате.

У другом примјеру се, као и у синдетској варијанти оваквих клауза, футуром исказује прихватање свих негативних посљедица ако се реализује радња из друге по реду клаузе:

Погинућу [ $\rightarrow$ Макар погинуо], њу не дам! 
Наравно, и у овим клаузама, исто као и у супротним клаузама са имплицитном концесивном семантиком, значење концесивности се остварује захваљујући томе што се координираним клаузама исказује специфична логичка импликација - у везу се доводе неадекватни, неочекивани основ и посљедица.

Условноконцесивну импликацију има и један специфичан тип асиндетских реченичних структура којима се исказује алтернативни подтип овог значења. ${ }^{4}$ Ове структуре имају комплекснију форму од претходно наведених. Будући да се њима исказује постојање минимално двије потенцијалне „отежавајуће" околности за реализацију имплицитно координиране предикације, карактерише их постојање дисјунктивне везе којом се исказују те околности, која, као цјелина, ступа на семантичком плану у концесивну релацију са том предикацијом. То су, дакле, асиндетске структуре у којима први дио има облик раставне конструкције. ${ }^{5}$ Овакве структуре регистровали смо само у књижевном и журналистичком поткорпусу:

Усnео не успео, ништа се више поправити не може. (Пекић, 41); Већина људи, слушала не слушала, једнако се понаша (...) (Рисојевић, 10); Хтио не хтио, Тигар је почео да запажа како му се међу овим омладинцима крави срце. (Ћопић, 125); Веровао ти или не веровао, тако је било. (Куић, 138); На крају, веровали или не, добио је и пензију! (Куић, 86); Противиш се, је ли? Противио, не противио, сажећи ћу читаву Подгорину, буде ли требало. (Ћопић, 159); Сањали-не-сањали, рекла је жена директора књижевних програма која нам се привукла иза леђа (...), хоћу да вечерас будете будни и да играте. (Албахари, 26); (...) као да се мири с некаквом великом невољом којој се, хоћеш-нећеш, већ сјутра мора жртвовати. (Ћопић, 16); Нагледаћеш се ти овога чуда па хтјела не хтјела. ${ }^{6}$ (Ћопић, 242); (...) ноћ није ту ништа могла да промени, помињали је или не. (Албахари, 45); Свеједно, дошао ја не дошао, очекујем да ће се и даље радити на побољшању програма (...) (НИН, 47); Осудили га или не, Благојевић је доказао да је у Америци заиста све могуће. (НИН, 73); Први су лутали по дрвореду крошњи међу којима је око, хтели то или не, добијало задовољавајућу дозу меланхолије (...) (НИН, додатак, 8); Они који прате Горчинове текстове и колумне (...) слагали се с ғим или не, морају признати да пише занимљиво (...) (Базар, 22) и др.

${ }^{4}$ Више о реченицама с алтернативним концесивним значењем в. Кубурић Мацура 2018.

${ }^{5}$ Овакве структуре И. Прањковић сматра погодбеним структурама: „Погодбене јукстапониране структуре у којима први дио има облик раставне конструкције (...) специфичне су по томе што и у једном и у другом дијелу раставне конструкције сусрећемо облике глаголског придјева радног (заправо оптатива) с погодбеним значењем, а и по томе што су дијелови таквих структура у тијесној међуовисности (функција раставне конструкције аналогна је функцији зависне клаузе у погодбеним реченицама), на примјер: Радио не радио - исто ти се пише; Крив или некрив (претпоставља се: био, И. П.), удри по реду” (Прањковић 2002: 155). Прањковић наводи и сљедеће: „У значењу наведених структура има нешто што би се могло описати као „раставна погодбеност” или „погодбена раставност”. Због високог ступња структурне петрифицираности, те су конструкције изразито стилски обиљежене. Најчешће се сусрећу у пословицама (и уопће у пословичним исказима) те у разговорном стилу" (Прањковић 2002: 177). Међутим, раставна конструкција, асиндетска или синдетска, као цјелина има алтернативноконцесивно значење, које се, истина, заснива на семантичком удруживању два опречна услова.

${ }^{6}$ Партикула па у овом примјеру додатно наглашава концесивну семантику конструкције. 
„Редупликоване” клаузе, тј. дисјунктивне клаузе у синдетској или асиндетској форми, поједностављено сведене на модел „А-не-А”/ „А или не-А”, које на семантичком плану успостављају концесивну релацију са асиндетском координираном клаузом, реализују се, у ствари, у неколико конкретних облика:

- $\quad$ глаголски придјев радни + његова одрична форма (нпр. хтио не $x т и о)$, тј. асиндетска форма раставне везе; ${ }^{7}$

- $\quad$ глаголски придјев радни + везник или + одрична форма глаголског придјева радног (нпр. веровао ти или не веровао);

- $\quad$ глаголски придјев радни + везник или + партикула не (нпр. веровали или не), тј. форма у којој је елидирањем избјегнуто понављање, ради економичности језичког израза;

- $\quad$ потврдни облик + одрични облик 2. лица презента (у нашем једином забиљеженом примјеру ради се о 2. лицу једнине: хоћеш-нећеш).

Концесивна семантика оваквих реченица заснована је на чињеници да оне, заправо, представљају комбинацију два потенцијална условна низа опречне семантике који срастају у један. При томе један од тих низова представља низ адекватног услова и посљедице, а други представља низ неадекватног услова и посљедице. На тај начин се у алтернативну, дисјунктивну везу доводе двије опречне ситуације, од којих је једна повољна за реализацију надређене предикације, а друга неповољна, а тиме се постиже и ефекат ирелевантности било повољног, било неповољног услова у том односу са надређеном радњом.

У свим адверзативним клаузама и асиндетским клаузама у којима се не јавља нека концесивна партикула или неки концесивни прилошки израз као конкретизатор везничког значења не можемо говорити концесивној семантици као јединој интерпретативној могућности. Другим ријечима, да би неке координиране клаузе могле да се сврстају у посебан семантички подтип - подтип са концесивном семантиком, морају бити испуњени и формални, синтаксички услови, о којима ћемо говорити у наставку.

\section{2. Адверзативне реченице с конкретизаторима концесивног значења}

У другу групу адверзативних реченица с концесивном интерпретацијом сврстали смо оне код којих је концесивна семантика потврђена и формално прецизирана језичким средствима са концесивном вриједношћу. Навешћемо

${ }^{7}$ Партикула свеједно у наведеном случају додатно указује на ирелевантност било које опције која се наводи у алтернативноконцесивној дисјунктивној вези. 


\section{овдје само један мањи број из читавог обиља примјера које смо регистровали приликом истраживања:}

Истина, редови гајтана, што су из појаса његова излазили и низали се по крајевима минтана, спрам свеће сјали су се од углачаности, али ипак сам минтан био је од свиле, скупоцен. (Станковић, 68); Младићу, моје неспособне колеге погрешиле су довевши вас до мене, али ја ћу вас, ето, ипак радо посаветовати (...) (Куић, 73); Зна Тигар добро да свака од њих већ унапријед зна какав је одговор, али ипак жели да га још једанпут чује (...) (Ћопић, 276); Није био одушевљен, могао сам то да му чујем у гласу, али ипак је прихватио. (Албахари, 229); Можда мртви могу себи да допусте неприкладно понашање, али она је ипак морала да води рачуна о обзирима. (Живковић, 53); Сигурно су се страшно плашили остављати јој своју кћер, али ипак су то чинили. (Јерговић, 143); Та сасушена нога је увек висила кад је хтео да се усправи и да мало постоји у месту, али је помагала при ходању, ипак. (Николић, 7); Буновни људи су веслали оштро, али јака матица их је ипак ухватила нешто раније него што је требало. (Андрић, 38); Осјећам како стоје нагомилане у магазама мога мозга, и вуку једна другу, јер су повезане, ниједна не живи сама за себе, $a$ опет има неког реда у тој гужви (...) (Селимовић, 12); Моји укућани воле савремена јела, али се ипак држимо и старих проверених. (Блиц жена, 30); Можда оваква поређења нису сасвим тачна, али ипак указују да је свет суочен са две различите врсте политичког понашања. (НИН, 68); (...) противник је онемогућио нашу пас игру, али $\underline{\text { }}$ поред тога постигли смо два гола (...) (Блиц, 30); Као најпрецизнији се показао специјални апарат за дељење таблета, али је упркос томе код 13 одсто таблета забележена грешка у дозирању. (Еуро Блиц, 11); Многи од оптужених нису стигли да се појаве у судници, али је првостепени суд у Сундсвалу констатовао да упркос томе не постоје препреке да суђење почне. (Глас Српске, 19); Споља се чинило да је најпажљивији муж и отац на свету, $a$ ипак је био све кривљи и кривљи и својим љубавницама и породици. (Капор, $71) ;(.$.$) да је живот несхватљиво чудо, јер се непрестано троши и осипа, a$ ипак траје и стоји чврсто „као на Дрини ћуприја”. (Андрић, 88); Све је било исто, $a$ све је, ипак, било различито. (Албахари, 15); Али није смео да ми се окрене целим лицем, еn face, него је говорио загледан у своју шољу из које је сркао белу кафу, чиме се још више издао, но ипак сам могао да видим да се није ни после толико година много изменио (...) (Киш, $112)$; Хангул је отуда ингениозан систем (...); но ово ипак не значи да је у пракси нужно надмоћан друкчије утемељеним системима писања. (Бугарски, 108) и др.

У овим реченицама, концесивна интерпретација није ослоњена искључиво на контекст, већ је потврђена конкретизаторима везничког значења неком од концесивних партикула или концесивних прилошких израза. Као конкретизатори концесивног значења везника могу се јавити партикула ипак и прилог опет, као и прилошки изрази и поред тога и упркос томе. Концесивни конкретизатор ипак се у језику најчешће појављује и може се рећи да је фреквентнији од свих осталих конкретизатора заједно.

Улога конкретизатора у наведеним спојевима је, на семантичком плану, необавезна - експлетивна, јер је њихова улога само да конкретизују тип адверзативног значења везника уз који стоје, тј. конкретизатор у оваквим примјерима служи само за спецификовање значења које је већ садржано у семантици адверзативног везника.

Концесивни конкретизатори значења адверзативнх везника могу се у реченици јавити у различитим позицијама, тако да можемо рећи да су пози- 
ционо слободни (наравно, уз ограничење да се увијек јављају у клаузи која се уводи везником). Ипак, као најчешћа се може уочити позиција конкретизатора непосредно уз везник (нпр. „Није био одушевљен, могао сам то да му чујем у гласу, али ипак је прихватио”; „Осјећам како стоје нагомилане у магазама мога мозга, и вуку једна другу, јер су повезане, ниједна не живи сама за себе, $a$ опет има неког реда у тој гужви (...)”; ,(..) противник је онемогућио нашу пас игру, али и поред тога постигли смо два гола (...)"; и др.); затим дистантна позиција (нпр. „Буновни људи су веслали оштро, али јака матица их је ипак ухватила нешто раније него што је требало”; „Као најпрецизнији се показао специјални апарат за дељење таблета, али је упркос томе код 13 одсто таблета забележена грешка у дозирању"; и др.), а као раритет се појављује и позиција конкретизатора на самом крају реченице у једном забиљеженом примјеру („Та сасушена нога је увек висила кад је хтео да се усправи и да мало постоји у месту, али је помагала при ходању, ипак”).

У језику нису ријетки ни случајеви да се концесивна релација изражава независносложеним реченицама у којима се концесивни конкретизатори везничког значења јављају уз саставне везнике $u$ и $n a$. Иако је основна функција ових везника да повезују елементе чији су садржаји у међусобном складу, њима могу бити повезани и садржаји који су међусобно нескладни или потпуно супротни, те у таквим случајевима могу бити замијењени адверзативним везницима (в. Прањковић 1984: 55).

Ова особина копулативних везника да исказују супротстављене садржаје представља основ за њихов додатни семантички потенцијал. Као подтип оваквог њиховог значења у језику се јавља и концесивни смисаони однос, али само када се уз њих употријеби конкретизатор концесивног значења (концесивна партикула, прилог или прилошки израз). ${ }^{8}$ Навешћемо неке од регистрованих примјера ове врсте:

И могли су наочиглед, пред свима, да се љубе, $n a$ ипак никоме не би могла да падне рђава мисао. (Станковић, 103); Никада јој ништа није забрањивано, па ипак то дете није било размаженије од осталих. (Капор, 142); Видим, $n a$ ипак сигуран нисам (...) (Пекић, 80); Никога није било ко би сматрао да је та ствар добра и могућна, па ипак свак је помало допринео да се хоџа нађе на мосту (...) (Андрић, 135); Изгледало је невероватно да три двојке изиђу готово једна за другом, $n a$ ипак је било тако. (Андрић, 170); Све то заједно ништа не значи, $n a$ ипак, слушалац као да наслућује смисао разговора. (Политикин Забавник, 28); Србин пије од рођења, па до смрти (...), na ипак су Срби генијална нација. (Еуро Блиц, 19); (...) оно је чврсто, па ипак веома лијепо (...) (Михајловић, 41); Човек је на њој као на чаробној љуљашци: и земљу прелази, и водом плови, и простором лети, $u$ опет је чврсто и сигурно везан за касабу и своју белу кућу, ту у страни, са баштом и шљивиком око ње. (Андрић, 106); Све он то добро зна $u$ све опет лако заборавља. (Андрић, 224); Овај човек ми се допада, одмах је помислила, али и закључила са дозом горчине да су јој се

${ }^{8}$ Д. Сааведра (2006: 225-226) наводи и примјер у којима се концесивни смисаони садржај исказује независносложеном реченицом са саставним везником $u$ (,Ја сам вас годинама бројао $u$ никако да вас пребројим.” Д. К.). 
током неколико последњих деценија живота многи мушкарци свиђали, na је упркос томе досад остала сама. (Куић, 187); Слушај, шупља главо, ти си вешт у овим крмковићима, знаш њихов језик и њихове марифетлуке, $n a$ и поред свега тога ниси у стању да пронађеш која је то рђа која се дигла да везирски посао квари. (Андрић, 36); и др.

У наведеним примјерима, уз копулативне везнике, статус конкретизатора концесивног значења другачији је него у случајевима када они стоје уз адверзативне везнике. Наиме, овдје су конкретизатори у исто вријеме и модификатори везничког значења, тако да представљају неопходан елемент чијим се елидирањем концесивна семантика губи - значење реченице се мијења или она постаје неграматична:

Изгледало је невероватно да три двојке изиђу готово једна за другом, $n a$ ипак је било тако. [ $\rightarrow$ * Изгледало је невероватно да три двојке изиђу готово једна за другом, $n a$ је било тако]; Све то заједно ништа не значи, $n a$ ипак слушалац као да наслућује смисао разговора. [ $\rightarrow{ }^{*}$ Све то заједно ништа не значи, $n a$ слушалац као да наслућује смисао разговора] и др.

Дакле, у оваквим случајевима, концесивна партикула ипак, прилог опет и концесивни прилошки изрази имају улогу обавезног конкретизатора, чак и модификатора везничког значења, на првом мјесту оспособљавајући саставни везник да повеже, на граматичан начин, два логички супротстављена садржаја, а потом му придајући и концесивну семантику. Овакве су реченице синонимне са реченицама са адверзативним везником, било са конкретизатором концесивне семантике или без њега, јер је основни услов за концесивну интерпретацију - супротстављеност садржаја у погледу очекивања и остварења - већ испуњен:

Изгледало је невероватно да три двојке изиђу готово једна за другом, $n a$ ипак је било тако. [ $\rightarrow$ Изгледало је невероватно да три двојке изиђу готово једна за другом, али

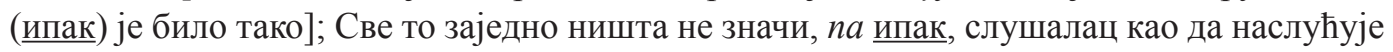

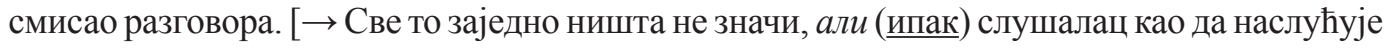
смисао разговора] и др.

Забиљежили смо и један примјер у којем се концесивна смисаона повезаност остварује помоћу везника $n a$ уз који није употријебљен концесивни конкретизатор/ модификатор везничког значења какав смо сретали у претходним примјерима. То је сљедећи примјер:

Видиш ме (обраћао се најближем до себе, не без гордости), педесет и пет ми је година пуних, na ја ㄸ данас до ручка обиграм све читлуке око Бугојна. (Андрић 2: 251)

Концесивна повезаност садржаја овдје, међутим, има упориште у интензификаторској партикули $u$ која је употријебљена уз временску одредбу „данас”, преносећи тако значење неадекватности - неочекиваности временске локализације ситуације на цијелу реченицу (,данас” = „када ми је педесет и пет година"). И овдје би се концесивна семантика ублажила елидирањем партикуле: 

око Бугојна.

*(..) педесет и пет ми је година пуних, na ја данас до ручка обиграм све читлуке

\section{ЗАКЉУЧАК}

Из наведене анализе можемо извести неколико закључака о координираним реченицама са концесивном семантиком.

Адверзативне, али и копулативне реченице могу, под одређеним семантичким и синтаксичким условима, имати концесивно значење. Први такав услов тиче се реченичног контекста - адверзативно повезани садржаји морају одсликавати суштину концесивне везе, тј. првом реченицом у таквој вези мора се исказивати ситуација која не представља адекватан основ за реализацију ситуације која се исказује другом по реду реченицом. Други услов, који вриједи само за синдетске адверзативне реченице, тиче се типа везника - за исказивање овог значења способни су само адверзативни везници али, $а$ и но, те копулативни везници па и $u$.

Највећи број адверзативних клауза које испуњавају један или оба ова услова имају узрочноконцесивну логичку импликацију, али под одређеним синтаксичким и семантичким околностима реализује се и условноконцесивна семантика. Овакве клаузе (са условноконцесивном вриједношћу) јављају се често и као асиндетске клаузе, при чему показују велику структурну разноврсност која се тиче прве клаузе/ дисјунктивне структуре, која је и носилац концесивне семантике.

Реченице које испуњавају или само први или оба ова услова (нужан услов логичке супротстављености и неиспуњеног очекивања и одговарајући везник) не могу се сматрати правим представницима концесивног семантичког подтипа координираних реченица, мада, евидентно, имају концесивно значење као саприсутно у својој адверзативној семантици. Све док није испуњен трећи, синтаксички најрелевантнији услов за концесивну семантичку интерпретацију координираних садржаја, концесивна компонента има непотврђен статус у семантици таквих клауза и представља тек једну од потенцијалних логичких импликација таквих садржаја.

Дакле, да би се веза координираних садржаја могла окарактерисати као веза са недвосмисленом концесивном семантиком, у реченици мора постојати неки елемент са концесивном вриједношћу који ће служити или као конкретизатор везничког значења (уз адверзативне везнике) или као његов модификатор (уз копулативне везнике). Те језичке јединице су концесивна партикула ипак, прилог опет и концесивни прилошки изрази. Исте јединице (unaк, onem, упркос томе, без обзира на то, и поред тога) јављају се и у улози конкретизатора значења (јер је концесивна семантика једна од потенцијалних импликација 
адверзативне везе) и у улози модификатора значења (оспособљавајући прво саставни везник за исказивање супротности, а затим му приписујући концесивну семантику).

\section{ИЗВОРИ}

Албахари 2001: Давид Албахари, Светски путник, Стубови културе, Београд.

Андрић 1978: Иво Андрић, Знакови, Сабрана дела Иве Андрића, Просвета - Београд, Младост - Загреб, Свјетлост - Сарајево, Државна заложба Словеније - Љубљана, Мисла - Скопје, Београд.

Андрић 1985: Иво Андрић, На Дрини ћуприја, БИГЗ, Београд.

Базар бр. 1191.

Блиц бр. 4867.

Блиц жена бр. 321.

Бугарски 1997: Ранко Бугарски, Писмо, Чигоја штампа - ХХ век, Београд.

Булатовић 1990: Миодраг Булатовић, Црвени петао лети према небу, Свјетлост, Сарајево.

Глас Српске бр. 12374.

еНовости: www.novossti.rswww.novossti.com (очитано 15.1.2013)

Еуро Блиц бр. 5003.

Живановић 2009: Миодраг Живановић, Eine Kleine Nachtmusik, Литера, Бања Лука.

Живковић 2006: Зоран Живковић, Мост, Лагуна, Београд.

Политикин Забавник бр. 3062, 15.10.2010.

Јерговић 2007: Миљенко Јерговић, Ruta Tannenbaum, Дани, Сарајево.

Капор 1995: Момо Капор, Последюи лет за Сарајево, БИГЗ, Београд.

Киш 2004: Данило Киш, Башта, пепео, Вијести, Подгорица.

Куић 2009: Гордана Куић, Преостале приче, Алнари, Београд.

Михајловић 2005: Бранислав Михајловић, Здравље почиње данас, No limits book, Београд.

НИН бр. 3113, 26.8.2010.

Николић 2004: Данило Николић, Краљица забаве, Политика, Народна књига, Београд. 
Пекић 2004: Борислав Пекић, Нови Јерусалим, Политика, Народна књига, Београд.

Рисојевић 2003: Ранко Рисојевић, Фрагменти, Бесједа - Бања Лука, Арс Либри - Београд.

Селимовић 1968: Меша Селимовић, Дервиш и смрт, Свјетлост, Сарајево.

Станковић 2004: Борисав Станковић, Нечиста крв, Политика, Народна књига, Београд.

Ћопић 1975: Бранко Ћопић, Глуви барут, Просвета - Београд, Свјетлост - Сарајево, Веселин Маслеша - Сарајево.

\section{ЛИТЕРАТУРА}

Ајановић 1953: М. Ајановић, „Независно” сложене реченице и однос простих реченица у њима, Наш језик, књ. V, св. 3-4, 134-147.

Ајановић 1954а: М. Ајановић, „Независно” сложене реченице и однос простих реченица у њима, Наш језик, књ. V, св. 5-6, 206-221.

Ајановић 1954б: М. Ајановић, „Независно” сложене реченице и однос простих реченица у њима, Наш језик, књ. V, св. 7-8, 278-291.

Белић 1954: Александар Белић, О сложеним реченицама и сродним појавама, Наш језик, књ. V, 227-234, 297-305.

Блох 1980: Ernst Bloh, Experimentum mundi, Beograd: Nolit.

Ковачевић 1988: Милош Ковачевић, Узрочно семантичко поље, Сарајево: Свјетлост.

Ковачевић 1998: Милош Ковачевић, Синтакса сложене реченице у српском језику, Београд: Рашка школа, Србиње: Српско просвјетно и културно друштво Просвјета.

Кубурић Мацура 2014: Мијана Кубурић Мацура, Систем синтаксичких кониесивних јединица у савременом српском језику, [необјављена докторска дисертација, одбрањена 2014. године на Филолошком факултету у Бањој Луци].

Кубурић Мацура 2018: Мијана Кубурић Мацура, Реченице с алтернативним концесивним значењем у савременом српском језику, Филолог, 17, Бања Лука, 34-51.

Милошевић 1986: Ксенија Милошевић, Синтаксички поступци за исказивање концесивних релација у сложеној реченици у српскохрватском 
језику и семантичка структура која се при том остварује, Научни састанак слависта у Вукове дане, 15/1, 33-45.

Пипер и др. 2005: Предраг Пипер и др., Синтакса савременога српског језика, Проста реченица, Београд: Институт за српски језик САНУ, Београдска књига, Матица српска.

Пипер и др. 2018: Пипер и др., Синтакса сложене реченице у савременом српском језику, Београд: Матица српска, Нови Сад, Институт за српски језик САНУ.

Пипер/Клајн 2017: П. Пипер, И. Клајн, Нормативна граматика српског језика, Нови Сад: Матица српска.

Прањковић 1984: Ivo Pranjković, Koordinacija u hrvatskom književnom jeziku, Zagreb: Sveučilišna naklada Liber.

Прањковић 2002: Složene strukture bez veznika, u: Hrvatska skladnja, Rasprave iz sintakse hrvatskoga standardnog jezika, drugo, izmijenjeno izdanje, Hrvatska sveučilišna naklada, Zagreb, 107-210.

Сааведра 2006: Димка Сааведра, Значење неких паратаксичких везника у српском језику, Зборник Матице српске за славистику, 70, 221-237.

Стевановић 1969: Михајло Стевановић, Савремени српскохрватски језик II, Синтакса, Београд: Научна књига.

\section{CONCESSIVE ADVERSATIVE SENTENCES IN SERBIAN}

\section{Summary}

This paper presents an analysis and systematization of concessive adversative sentences in Serbian. The majority of such adversative clauses carry a causal-concessive logical implicature, but under certain syntactic and semantic circumstances, conditional-concessive meaning occurs. Such clauses (with conditional-concessive meaning) often occur as asyndetic clauses, with vast structural diversity of the relevant main clause. Sentences which meet only the necessary requirement of logical adversiveness and unfulfilled expectation, with a corresponding conjunction word, cannot be considered true representatives of the concessive semantic subtype of coordinated sentences, although, evidently, concessive meaning is present alongside its adversative semantics.

The third, syntactically most relevant condition for concessive semantic interpretation of the coordinated content - the presence of a specifier or modifier of the conjunctive 
meaning, the concessive component is but one of many potential logical implicatures of such content.

Keywords: concessiveness, adversativeness, specifier of conjunctive meaning, modifier of conjunctive meaning.

Mijana Č. Kuburić Macura 